\title{
TWO BLOCKS FROM THE EXCAVATIONS OF CAIRO UNIVERSITY IN HELIOPOLIS KEPT AT THE MUSEUM OF THE FACULTY OF ARCHEOLOGY, CAIRO UNIVERSITY
}

\author{
Hayam Hafez RAWASH \\ Faculty of Archaeology, Cairo University \\ E-mail: hhafez762@gmail.com
}

\begin{abstract}
This article publishes two blocks from Heliopolis, discovered during the Faculty of Archaeology's excavations at the ancient Egyptian city of Ounû to the northeast of Cairo, The area is currently known as Tell el-Hisn or Arab el-Hisn. The two blocks are stored at the Museum of the Faculty of Archaeology, Cairo University.

1. The Block of Ramesses II: A rectangular block with a finely engraved scene depicts a figure of the Nile-god Hapy in a kneeling posture, lifting on his hands a flat offering-table presenting to the cartouche of Ramesses II. On his head, there is a symbol of an unknown district. The offering table is laden with a heap of offerings consisting of bread, birds of the marshes, and papyrus plants. The block has three registers of hieroglyphic texts.

2. The Block of Ramesses V: A rectangular block depicts a scene of a destroyed figure of the king Ramesses $\mathrm{V}$ crowned with the blue diadem and uraeus, kneeling and doing fumigation and libation before a seated baboon, the sacredfigure of the god Thot. The latter, is represented in the form of a seated baboon wearing the necklace of Ma'at with a headdress, consisting of the lunar disk on top of a crescent moon The scene is accompanied with three cartouches and a short hieroglyphic texts.
\end{abstract}

يتعلق موضوع البحث بنشر كتلتين من هليوبوليس، عُثر عليهما أثناء حفائر كلية الآثار فى مدينة أونو القديمة التي تقع إلى الثمال الثرقي الثراء

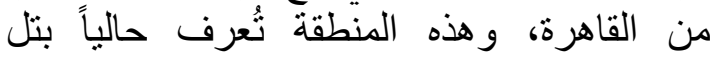

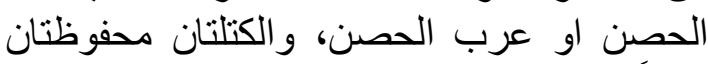
حالياً بمتحف كلية الآثار جامعة القاهرة. 1-كتلة الملك رمسيس الثاني:كتلة مستطبلة الثكل

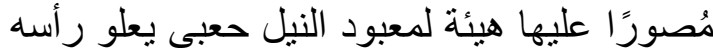
رمزاً لإقليم غير معروف، هُو راكعاً مُقدما القر اببين لخرطوش الملك رمسيس الثاني، وتحتوي معائدة

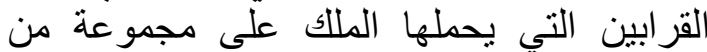

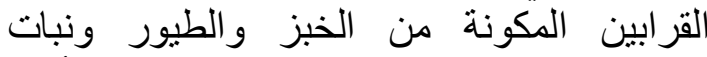
البردي، ويصاحب المنظر ثناثنة صفوف رابن رأسية

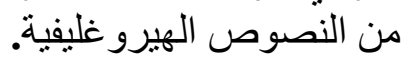
2-كتلة الملك رمسيس الخامس: كتلة مستطيلة

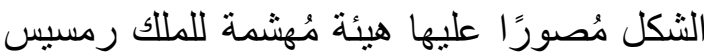

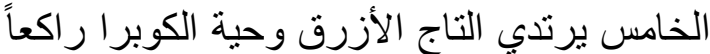
ويقوم بعمل التبخير والتطهير أمام قرد البابون، الهيئة المقدة للمعبود جحوتى، وقد صنو لئور القرد

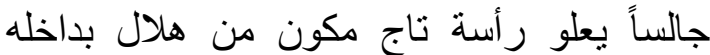

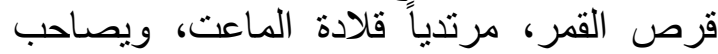

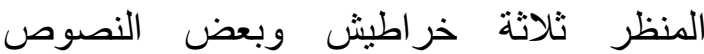

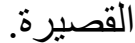

\section{KEYWORDS}

الكمات الدالة

Heliopolis, Tell el-Hisn, Ramesses II, Ramesses V, Hapy, The god Thoth, offerings, fumigation, libation.

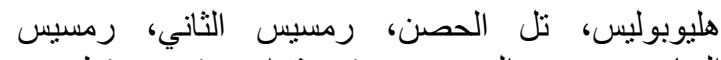
الخامس، حعبى، المعبود جحوتى، قر ابين، تبخير، تطهير.

- 36 - SHEDET Issue nu. 6 (2019), pp. 36-57 


\section{INTRODUCTION}

This article aims to publish two blocks from Heliopolis, the ancient 'Iwnw', capital of the thirteenth district of Lower Egypt. ${ }^{1}$ The blocks were found during the Faculty of Archaeology's systematic investigation of this site of the ancient Egyptian city of Ounû ${ }^{2}$ to the northeast of Cairo. It is currently known as Tell el-Hisn or Arab el-Hisn to the north of El-Matariyah district. The excavations were inaugurated in January 1976 and were carried out for six seasons up to $1981 .^{3}$ A. Saleh continued earlier Cairo University excavations by the Egypt Antiquities Organisation that had made important discoveries. ${ }^{4}$ Because of the archaeological and religious importance of Heliopolis, many excavations took place at this site. However, the most important excavations were the excavations of the joint EgyptianGerman Mission that made valuable discoveries ${ }^{5}$.

The recent excavation of Ain Shams University under the supervision of M. Eldamaty held during two seasons, remains unpublished. However, it revealed, during the first season in October 2017, a religious complex and ceremonial palace dating to the Ramesside period. At the end of the second season in April 2018, a unique ceremonial chapel of Ramesses II was discovered, used for royal celebrations. It is considered to be the first of its kind for the New Kingdom. A collection of mud-brick walls of a casemate building was also revealed, dating at its earliest stage to the Ramesside Period, and being used until the Late Period. The mission revealed many artefacts dating to this chronological range. ${ }^{6}$

\section{1- The Block of Ramesses II (Pls.1-4, fig.1).}

Material: Limestone

Height: $87 \mathrm{~cm}$

Width: $61 \mathrm{~cm}$

Thickness: $11 \mathrm{~cm}$

Place of preservation: Museum of the Faculty of Archaeology, Cairo University, no.1755814.

State of preservation: The relief and hieroglyphs are in a fairly good state of preservation.

\footnotetext{
${ }^{1}$ Iwnw was the centre of the god Nwn, see: Selon, W.M.V., Egyptians Legends and Stories, London, 1988,712;Banies, J. F\& Melek, J., Atlas of Ancient Egypt, NewYork, 1964, 173; Allen, J 'Heliopolis', OEAE II, 8889; for more information see: Loo, A.V\& Bruwier, M.C., Héliopolis , Bruxelles, 2010.

${ }^{2}$ The two blocks were attested by A. Saleh in his preliminary report of the Excavations in Heliopolis, see: Saleh, A, Excavations at Heliopolis, Ancient Egyptian OUNU, vol. II, Cairo, 1983, 63-64, fig 17.

${ }^{3}$ Saleh, A, Excavations at Heliopolis, Ancient Egyptian OUNU, vol I, Cairo, 1981, III- IV, 4.

${ }^{4}$ See: Moursi,M., 'Die Hohenpriester des Sonnengottes von der Frühzeit Ägyptens bis zum Ende des Neuen Reiches', $M \ddot{A} S$ 26, 1972.

${ }^{5}$ About the excavations of the joint Egyptian-German Mission see: Ashmawy, A \& Raue, D \& Beiersdorf, M., 'The Thirtieth-Dynasty in the Temple of Heliopolis', in: Egyptian Archaeology EES-Bulletin 47, 2015, 13-16; Ashmawy, A \& Raue, D., 'The Temple of Heliopolis: excavations 2012 -2014', Egyptian Archaeology EES-Bulletin 46, 2015, 8-11; De Dapper, M \& Herbich, T., 'Geomorphological and geophysical survey', in: Egyptian Archaeology EES-Bulletin 46, (2015), 12-13; Maria, S.A., e-excavating Heliopolis, Unpublished Archaeological Data from the Archives of Ernsto Schiaparelli and Missione Archeologica Italiana, 2014, 278293; Essam, B., 'Le Voyage à Héliopolis descriptions des Vestiges Pharaoniques et des Traditions Associées depuis Hérodote jusqu'à l'Expédition d'Égypte', RAPH 36, Cairo, 2014, 185-212; Abd el-Gelil, M \&Suleiman, R\& Faris, G \&Raue, D., 'The Joint Egyptian-German Excavations in Heliopolis in Autumn 2005, in: MDAIK 64, 2008.

${ }^{6}$ Eldamaty, M., 'Recent Excavations at Arab el-Hisn', A lecture in' Daily Life in Ancient Egyptian Settlement, Conference to Celebrate the fiftieth Anniversary of Excavations on Elephantine Island, May 2019.
}

- 37 - DOI: $10.36816 /$ shedet.006.3 


\section{Description:}

A rectangular block was found among the debris of the Temple of Ramesses IV. It lost the edges of its upper parts. It is divided into four vertical registers. The third register depicts the scene, while the first, second, and fourth registers contain the hieroglyphic texts. This block is probably a balustrade. ${ }^{1}$ A. Saleh suggested that the block would have been dislodged from the older panels of the balustrade wall of the temple. ${ }^{2}$

\section{The scene:}

A finely engraved scene depicts a figure of the Nile-god Hapy ${ }^{3}$ in a kneeling posture, lifting, on his hands, a flat offering-table presenting the cartouche of Ramesses II. ${ }^{4}$ Hapy is frequently portrayed as a plump man with women's breasts, a protruding belly, and blue or green skin adoring also the false beard of the pharaoh.

The breasts, the belly, and the colour of the skin symbolise his fertility and ability to nourish the land and the harvest through the Nile's annual floods. Moreover, the two breasts may also refer to the two caves from which the Nile stems, ${ }^{5}$ while the false beard reaffirms his link to the pharaoh. ${ }^{6}$ On his head, there is the symbol of an unknown province. ${ }^{7}$ The offering table upon his hands is laden with a heap of offerings that consists of bread, birds of the marshes, and papyrus plants.

\section{The texts:}

The text of this block may be compared to similar texts, such as one from the Temple of Amenhotep III at Wadi es-Sebua, ${ }^{8}$ and one from the Temple of Osiris dating to the reign of Sety I at Abydos ${ }^{9}$. The closest texts to the present block's text are for one recorded on the eastern wall of the second pylon of the Temple of Rameses III in Medinet Habu Hence, the missing parts of the text in this block of the Temple of Ramesses IV could be traced and $\operatorname{read}^{10}$ :

\footnotetext{
${ }^{1}$ The storerooms of the house at El-Matariyah have similar blocks dating to the reign of Amenhotep III that were on display for many years in the Open__Air Museum of El-Matariyah. Still there is a similar object on site in the old concession of Cairo University and another one is found on the archive photos of Turin Museum (Schiaparelli, 1903 - 1906, about balustrades blocks in the New Kingdom period. See: Shaw, J., 'Balustrades, Stairs and Altars in the Cult of the Aten at el-Amarna', JEA 80, 1994, 109-127.

${ }^{2}$ Saleh, A., Excavations at Heliopolis, , vol. I, 53, pl.XV B.

${ }^{3}$ WbIII,42,15; Hannig, R., Ägyptisches Wörterbuch II, Mittleres Reich und Zweite Zwischenzeit, Teil I, Mainz Am Rhein, 2006, 512-13.

${ }^{4}$ A.Saleh suggested that Hapy presenting offerings to the king Ramesses IV indicates that he is the god of the temple, see: Saleh, A., Excavations at Heliopolis, II, 63.

${ }^{5}$ Barguet,P., 'La Stèle de La Famine à Sehel', in: BDE 23, 1953, 12-13.

${ }^{6}$ Wilkinson, R.H.,The Complete Gods and Goddesses of Ancient Egypt, Thames \& Hudson, 2003, 106-107; White,M., Ancient Egypt ,London,1992, 33.

${ }^{7}$ Saleh, A., Excavations at Heliopolis, II, 63-64, fig 17.

${ }^{8}$ Firth, C.M., The Archaeological Survey of Nubia Report for 1910-1911, Cairo, 1927, pl.31-32.

${ }^{9}$ Petrie, F., Abydos II, EEF 24, 1903, pl.35.1.

${ }^{10} \mathrm{~A}$. Saleh read the text as: '(at) the beginning of the inundation, I bring to you all good things (upon) the hands of thy son the lord of the two lands , Weser-maet-Re, Setepen-Re given life ........, and (at the beginning of the inundation, I bring to you all good fresh vegetables '.see: Saleh, A, Excavations at Heliopolis, 63.
} 

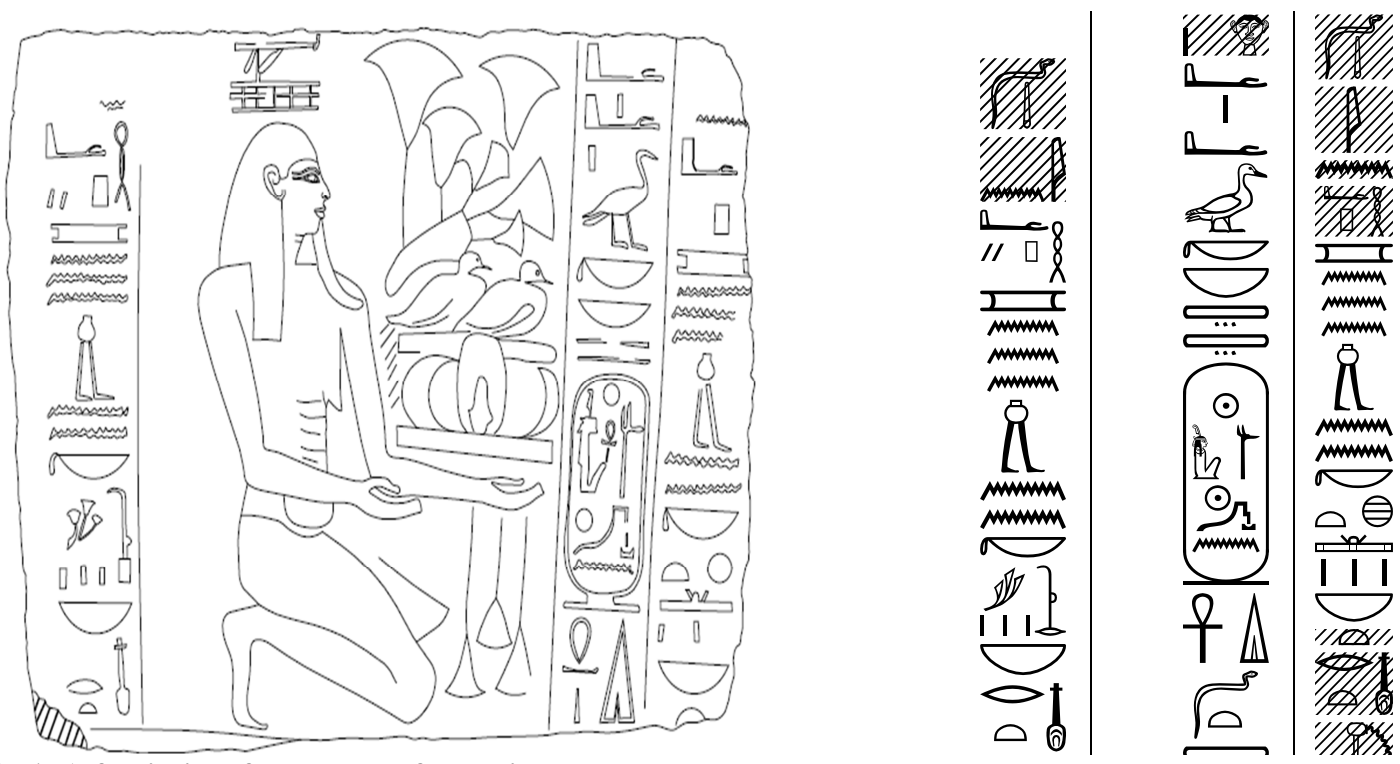

Fig.1. A facsimile of the block of the King Ramesses II

\section{Transliteration:}

${ }^{[1]}$ [dd $m d w$ in $\left.H^{\top} p y\right]$ in. (i) $n . k$ ht $n b(t)$ (nfrt)

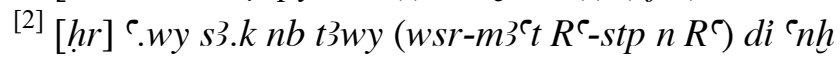

${ }^{[3]}$ [dd $m d w$ in] H'py in. (i) n.k rnpwt ht $n b(t) n f r t$

\section{Translation:}

[1] [Spell by Hapy]: I brought to you every beautiful thing.

[2] [On] the two arms of your son the Lord of the Two Lands (Weser-Ma'at Re, setepen-Re) given life.

${ }^{[3]}$ [Spell by] Hapy: I brought to you every beautiful vegetable.

\section{Comment:}

a- Although this stela was found among the debris of the Temple of Ramesses IV, the recorded title in the cartouche $\left(W s r-m 3^{\top} t-R^{\top} s t p-n-R^{\top}\right)$ is the title of Ramesses II. ${ }^{1}$ This suggests that the block was taken from a place constructed by Ramesses II near the Temple of Ramesses IV. It may be the Temple of Ramesses II in Tell-el Hisn, Heliopolis, ${ }^{2}$ which was located at the same site where this stela was found. Thus, this block was designed for a structure of Ramesses II but was reused by Ramesses IV. ${ }^{3}$

\footnotetext{
${ }^{1}$ Von-Beckerath, B., 'Handbuch der Agyptischen Konigsnamen', M̈̈S 20, 1984, 89-90.

${ }^{2}$ Abd-el-Gelil, M \& Shaker, M \& Raue ,D.,'Recent Excavations at Heliopolis', in: Or 65, 1996, 136146;Balboush,M., 'Preliminary Export on the New Discovery of the Temple of Ramesses II at Heliopolis', in: ASAE 63, 1979, 7-33; Mouris, M.I \& Balbousch, M.,'Funde aus dem Temple Ramses II‘ im Tell el-Hisn bei Heliopolis', in: MDAIK 31, 1975, 85-91.

${ }^{3}$ The Reuse of stelae and statuary of ancestors was common in Ancient Egypt.Ramesses II reused statuary of Senusret I in his temple in Tell-el Hisn, Heliopolis. See: Abd-el-Gelil,M \&Suleimam,R \&Faris, G \& Raue, D., 'The Joint Egyptian-German Excavations in Heliopolis in Autumn 2005', in: MDAIK 64, 2008, 7-8;
} 
b- Depicting Hapy 'presenting offerings' is related to two matters:

1- The relationship between Hapy and the offerings depends on his central role in the Egyptian religion as a god of water and fertility. He was responsible for supplying Egypt with water, food, and yearly inundation of the Nile ${ }^{1}$ and henceforth providing gods and people with offerings. ${ }^{2}$ One of his titles was the 'Lord of the fish and birds of the marshes 'indicating that he provided these goods to Egypt and the Egyptians along with the Nile itself. ${ }^{3}$ Therefore, many religious texts indicate the relationship between Hapy and the offerings, such as:

*'Hapy is the one who supplies the gods with offerings' ${ }^{4}$

*'I am Hapy who brings offerings ${ }^{6} .5$

The offering table of Hapy, as seen in the block, always contains all the goods he supplied Egypt with, such as birds of the marshes, fish, fruits, vegetables, and papyrus. ${ }^{6}$ They were a precious gift on altars and offering tables in temples as a natural symbol of life and the primeval marsh from which all life came. ${ }^{7}$

He is depicted in his most common posture in temples, stelae, and statues, he was presenting offerings to gods, kings, or their cartouches. For instance,

*A relief on the southern wall of the sanctuary of the god Ra-Hor-akhty shows Hapy presenting offerings to the god. ${ }^{8}$

* A relief from the reign of the king Horemheb at Karnak depicts Hapy as presenting offerings to the goddess Renenūtet. ${ }^{9}$

* A relief on an altar from the reign of the king Amenemhat I at the Metropolitan Museum 09180527 presents Hapy with fertility figures offering goods to the cartouche of the king. ${ }^{10}$

Raue, D., Ein Wesir Ramses' II. in: Stationen, Beiträge zur Kulturgeschichte Ägyptens Rainer Stadelmann gewidmet. (ed.) by Heike Gusch, H \& Polz.D, Mainz, 1998, 341ff.; Sourouzian, H. 'Statues et representations de statues royales sous Sethi I', in: MDAIK 49, 1993, 239ff; Id.,' Standing royal colossi of the Middle Kingdom reused by Ramesses II', in: MDAIK 44, 1988, $29 \mathrm{ff}$.

${ }^{1}$ Because of his vital importance to all living, many praising hymns were dedicated to this deity, see: Assmann, J., 'Nilhymnus, 'L $\ddot{A}$ IV, 489-496. For the text itself, see: Spence, L., Myths \& Legends of Ancient Egypt, NewYork, 2008, 171; Helck,W., Der Text des 'Nilhymnus ' (Kleine ägyptische Texte, 4; Wiesbaden: Otto Harrassowitz, 1972.

${ }^{2}$ Barguet, P., Le Temple d' Amon-Ré à Karnak, in: RAPH 21, 1962, 274.

${ }^{3}$ Ions,V., Egyptian Mythology, Italy, 1982, 107.

${ }^{4}$ Pyr. 1553 b, 1554.

${ }^{5} C T \mathrm{~V}, 11 \mathrm{G}$.

${ }^{6}$ Roader,G, Kulte und Orakel in Alten Ägypten, Zurich,1960, 317.

${ }^{7}$ Rosemarie, D., 'Papyrus, -herstellung', in: $L \ddot{A}$ IV, 667 670; Weidner, S., Lotos im Alten Ägypten, vorabeiten zu einer Kulturgeschichte von Nymphaea Lotos,Nymphaea Coerulea und Nelumbo Uncifera in der Dynastischenzeit, 1985, 24.

For more about papyrus and lotus see: Richard, P\& Quirke, S., Papyrus, London, 1995; Bierbrier, M. L. (ed), Papyrus: Structure and Usage. British Museum Occasional Paper 60, London, 1986; Hassan, R., Le Papyrus, Cairo, 1980; Naphtali, L., Papyrus in Classical Antiquity, Oxford, 1974.

${ }^{8}$ Baines, J., Fecundity Figures: Egyptian Personification and the Iconology of a Genre, Warminster, 1985, fig.188.

${ }^{9}$ Barguet, P., Le Temple d' Amon-Ré à Karnak, in: RAPH 21, 1962, 274; Baines, J., Fecundity Figures, fig.53. 
* A stela from the reign of Sobek-hotep VIII (16th dynasty) depicts Hapy as presenting offerings to the king. ${ }^{1}$

*A relief from the reign of Amenhotep III at Cleveland Museum 61205.76.51 shows Hapy with province figures as presenting offerings to the king. ${ }^{2}$

2-The figure of Hapy presenting offerings with the province symbol on his head illustrates geographical processions in Ancient Egypt ${ }^{3}$, with the personifications of provinces of Egypt offering their produce ${ }^{4}$ as in this scene.

Many reliefs show Hapy either presenting offerings or performing the sema-tawy ritual. In both positions, he wears different headdresses ${ }^{5}$. In our scene, the god Hapy was depicted as a personified province thanks to the symbol on his head, which in this instance, is undetermined.

c- The relationship between Hapy and Heliopolis, the ancient (Iwnw) may be derived

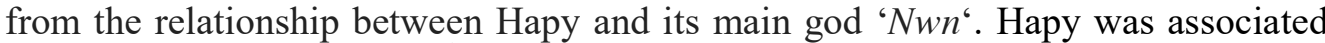
with the creator god Nun, ${ }^{6}$ as he was believed to be located somewhere in the watery chaos of Nun's domain. He was thought to have flowed from the primeval waters of $N w n$, before becoming an aspect of $N w n$, the primeval water from which all things emerged. In some cases, the high inundation ${ }^{7}$ also was called $n w n^{8}$.

\footnotetext{
${ }^{1}$ Radwan, A.,'Zur Stellung des Königs in der Zweiten Zwischen Zeit', in: TÄB 30, 1990, TF18a; Baines, J., 'The Sebekhotpe VIII Inundation Stela, An Aditional Fragment', in: AcOr 37, 1976, 11-20; Id.,'The Inundation Stela of Sebekhotpe VIII', in: $\mathrm{AcOr}$ 36, 1974, 39-54; Habachi, L., 'Hight Inundation in the Temple of Amenre at Karnak in the $13^{\text {th }}$ dynasty', in: $S A K 1,1974$, TF.1.

${ }^{2}$ Baines, J., Fecundity Figures, 90,fig.56.

${ }^{3}$ The joint Egyptian-German Mission at El- Matariyah in 2015/2016 discovered the Temple of Nectanebo I to the southeast of the obelisk of Sesostris I, in which basalt blocks and slabs are adorned with the geographical procession. The reliefs represent the first to eighth nomes of Upper Egypt. Some of the scenes are completely preserved,see: Ashmawy, A \& Raue, D \& Recklinghausen, Daniel,R., Von Elephantine bis zu den Küsten des Meeres: Die Kulttopographie Ägyptens nach den Gauprozessionen der Spätzeit und der frühptolemäischen Epoche, Studien zur spätägyptischen Religion, 24, Gebundenes Buch, August 2019; Ashmawy, A\& Raue, D\& Breninek, C\& Dietze, K\& Graichen, T\&Schulz, S., Report on the work of the Egyptian-German Mission at Matariya/Heliopolis in autumn 2015 and spring 2016; Thews,J.,Weitere Funde zum Heiligtum des Nektanebos I. in Heliopolis, Mai 2016.

${ }^{4}$ Benezet, N.T. , 'Géographie Sacrée dans l'Egypte Ancienne : Méthodologie et Perspectives à partir de l'Etude du Territoire des Deux Sceptres - wAs', Bellaterra, 2012, 22ff; Johnston, S.I., Religions of the Ancient World, Cambridge University Press, 2004, 396; Assmann, J., The Search for Gods in Ancient Egypt, Cornell University Press, 2001, 37; Rodot,V\& Gabolde, L., 'Karnak, Precinct of Montu', Encyclopedia of the Archaeology of Ancient Egypt, ed.by K.A.Bard, NewYork, 1999, 396.

${ }^{5}$ In the case of depicting Hapy as the patron of Lower Egypt ' $h$ ' $p y-m h y t$ ', he was depicted wearing papyrus plants headdress as a symbol of Lower Egypt. As the patron of Upper Egypt ' $h{ }^{\prime} p y-r s y t$ ', he was depicted wearing lotus plants headdress as a symbol of the south on his head. When he was depicted as the god of the entire Nile, he held both lotus and papyrus plants in his hands and two vases. For more information, see: Marwan, N. Z., Egyptian Agriculture Life in the New Kingdom, Cairo, 1989; Jéquier,G., Le Monument Funéraire de Pépi, II , (Le temple), Le Caire, 1938, fig. I.

${ }^{5}$ Wolf, W., Die Kunst Äegypten, Leipzig, 1959, fig.53; Bakry, H.S., The Discovery of Temple of Mernptah at On, in: Aegyptus 53, 1973, pl.13; Evers,H.G,Staat aus dem Stein vol. I, München,1929, pl.117; Baines, J., Fecundity Figures, fig.138; PM II,313; Patrik, K., All Colour Book of Egyptian Mythology, London, 1989, $16 \mathrm{ff}$.

${ }^{6}$ Hart, G., The Routledge Dictionary of Egyptian Gods and Goddesses, Routledge, 2005, 85-86.; Wessetzky,V.,'Nun', in: $L \ddot{A}$ IV, 534.

${ }^{7}$ Brunner,T., 'Schötung',in: L $\ddot{A} V I, 677-690 \mathrm{ff}$.

${ }^{8}$ Bonneau, D., La Cure du Nil, Divinité Égyptienne à Travers Mille Ans d'histoire, Études et Commentaires 52, Paris, 1964, 239.
}

- 41 - DOI: $10.36816 /$ shedet.006.3 
Sometimes the primeval god replaced Hapy in his offerings; the formula was then "dd $m d w$ in $n w n "$. Many texts established the relationship between the two gods, such as a stela from Gebel es-Silsila mentioning:

'Nwn mry h'py it $n t r^{1}$

'Nun, the beloved of Hapy the father of the gods'

d- The main recorded formula is ' $d d m d w i^{2} h^{C} p y$ ' 'a spell by the god Hapy'. In some similar texts, the letter ' $n$ ' in the particle ' $i n^{\text {' }}$ in the formula was written with the sign 13 instead of mmm ${ }^{3}$ This feature is common in the New Kingdom.

\title{
2. The Block of Ramesses V (Pls.5-7, fig.2)
}

\author{
Material: Limestone \\ Height: $45 \mathrm{~cm}$ \\ Width: $42 \mathrm{~cm}$ \\ Thickness: $11 \mathrm{~cm}$ \\ Place of preservation: Museum of the Faculty of Archaeology, Cairo University, no.118- \\ 812. \\ State of preservation: The relief and hieroglyphs are in fairly good state of preservation.

\section{Description:}

A rectangular block was found in Heliopolis. It had lost all four edges but comprised a scene of a destroyed figure of the king Ramesses $\mathrm{V}$, a complete figure of a baboon accompanied with three cartouches, and a short hieroglyphic texts. This block could have belonged to a lintel, as it resembles temples' doorways lintels from the New Kingdom. ${ }^{4}$

\section{The scene:}

The scene shows part of the figure of the king Ramesses V crowned with the blue diadem and uraeus, ${ }^{5}$ kneeling, fumigating and performing libation from armless vessels ${ }^{6}$ before the sacred-figure of the god Thoth ${ }^{7}$, who is represented in the form of a seated baboon with a headdress of the lunar disk on top of a crescent moon, wearing the necklace of Ma'at.

\footnotetext{
${ }^{1}$ Stern, L., 'Die Nile Stele von Gabel Silsileh', in: Z̈̈S 1, (1873), 130.

${ }^{2} \mathrm{~Wb}, \mathrm{~V}, 625-626$; $L D L E$, II, 275.

${ }^{3}$ See, for example, a text from the Temple of Ramesses III at Medinet Habu, MHV, pl.259A.

${ }^{4}$ Wilkinson, R.H., The Complete Temples of Ancient Egypt, Thames \&Hudson, 2000, 88ff; Hovestreydt, W., 'Secret Doors and Hidden Treasure: Some Aspects of Egyptian Temple Treasuries from the New Kingdom', in: Egyptological Memoirs 1, Essays on Ancient Egypt in Honour of Herman te Velde,ed.by J.Van Dijk,Groningen,1997,187-204,fig.1-4.

${ }^{5}$ Saleh, A., Excavations at Heliopolis, II, 63, 66, fig. 18.

${ }^{6}$ The armless censers were the most common censers in the New Kingdom period, see: Beinlich, H.,Ein., 'Altagyptischen Raucheram', in: MDAIK 34, 1987, 24-25; Fischer, H.,'Varia Aegyptiaca 4, The Evolution of Arm like Censer',in: JARCE 2, 1963, 30-31.

${ }^{7}$ The god Thot was one of the most important gods in the Ancient Egyptian religion. He had two sacred animals; the ibis and the baboon. For more information about his aspects and his roles in the Ancient Egyptian religion, see: El-Sayed, A. M., La Mythologie Egyptienne, Paris , 1998, 106; D. Kessler, 'Der Gott Thot-stier',in: D. Kessler \& R. Schluz (Hrsg.), Gedenkschrift für winfried Barta, htp di $n$ hzj, Frankfort, 1995, 229-245;Brunner-Traut,E., 'Affe', in: L̈̈ I, 83ff; Zivie, A.,'Ibis',in: L̈̈ III, 115ff; Boylon, P., Thoth,The Hermes of Egypt, Oxford, 1922, 5ff.
} 


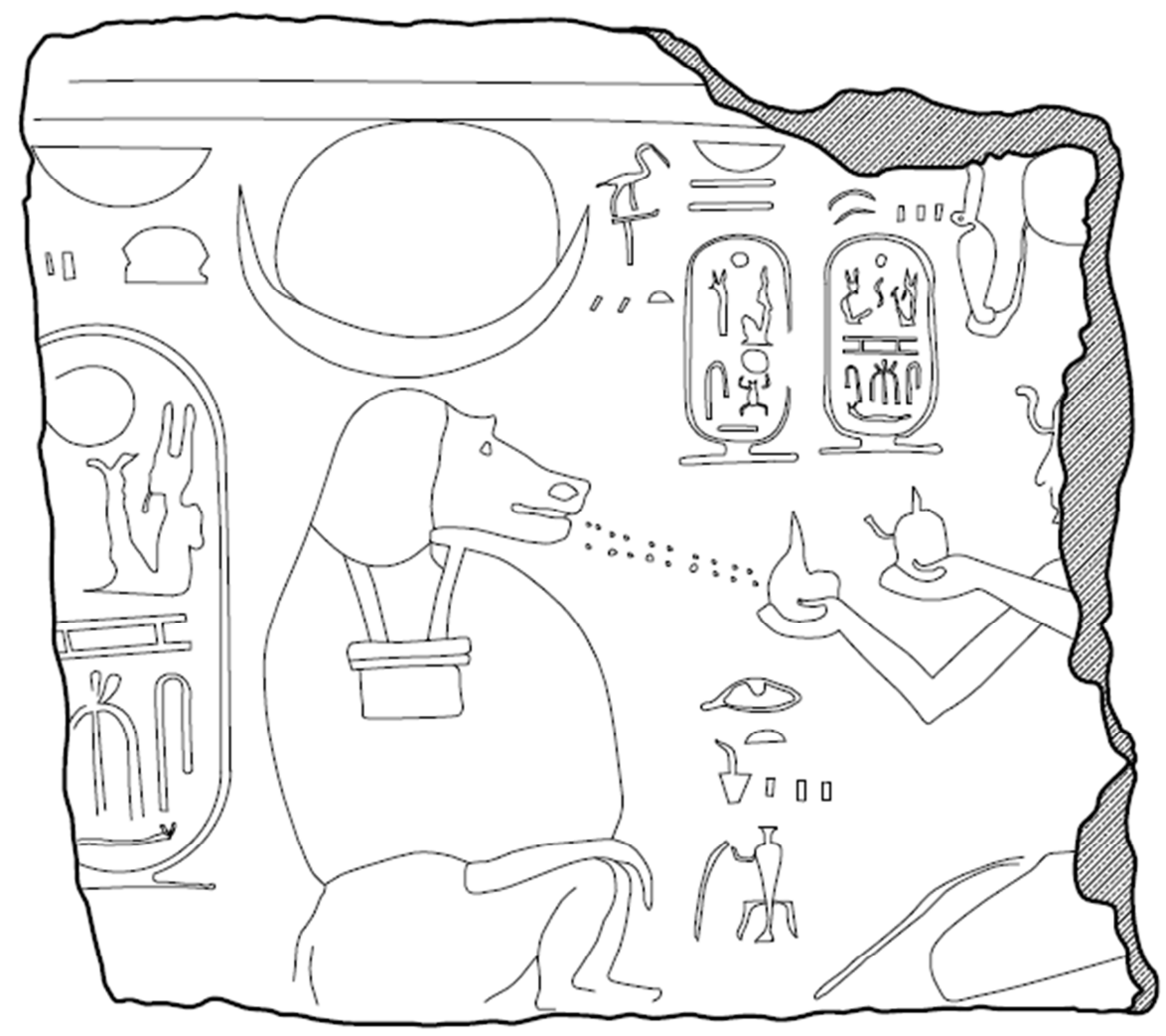

Fig.2. A facsimile of the block of the king Ramesses V

\section{The texts:}

In front of the king's head, there are two cartouches:

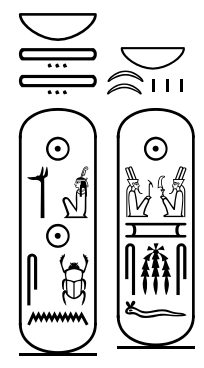

$n b-t 3 w y\left(W s r-m 3^{\top} t-R^{\top}, \operatorname{shpr}-n-R^{\top}\right),[n b]-h^{\complement} w\left(R^{e}-m s-s(w) . f^{l}, m r y-\operatorname{Imn}\right) .^{2}$

'The Lord of the Two Lands (Weser- Ma'at -Re, sekheper-en-Re),The Lord of appearance, Ramesses the beloved of Amon'.

Under the king's arms, there is a short text:

\footnotetext{
${ }^{1}$ In the two cartouches containing the name of the king $\left(R^{e}-m s-s w\right)$ the writer used the suffix pronoun (f) instead of (sw), see : KRI,VI,221,14.

${ }^{2}$ The sign before the cartouche may be an abbreviated writing of $n b-h{ }^{\top} w \curvearrowright$
} 


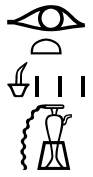

Irt-sntr k kbh

'Doing fumigation and libation'.

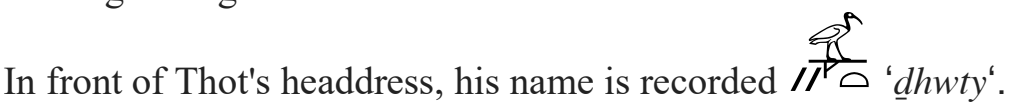

Behind Thot, a short text is written:

$\varlimsup_{1,18}$

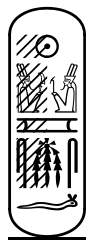

$n b-h{ }^{\complement} w\left(R^{\top}-m s-s(w) . f, m r y-' T m n\right)$.

'The Lord of appearance, Ramesses the beloved of Amon'.

\section{Comments:}

a- The block belongs to Ramesses $\mathrm{V}$ as the cartouche had the title (Wsr-m3`t-R ${ }^{\mathrm{C}}$, shpr$\left.n-R^{\top}\right)^{1}$

b- Depicting the king in the company of the gods, presenting it offerings, doing the presentation of Ma'at or doing fumigation and libation, as in the current stela, is important for the balance of the Egyptian universe. According to the Ancient Egyptian religion, the Egyptian universe was surrounded by endless and unknown darkness, dangerous to all creation. Therefore, it had to be kept at bay by preserving Ma'at with the support of the gods, except for few deities who disrupted the divine order, ${ }^{2}$ against the representatives of 'jsft' darkness and chaos. ${ }^{3}$

The king, as someone extraordinary ${ }^{4}$, played a mediator role between his people and the gods and was responsible for their care. ${ }^{5}$ He was principally responsible for keeping Ma'at $^{6}$ the regularly depicting of the king in the accompaniment of gods, worshiping

\footnotetext{
${ }^{1}$ Von-Beckerath, B., 'Handbuch der Ägyptischen Konigsnamen',in: $M \ddot{A} S$ 20, 1984, 95.

${ }^{2}$ Traunecker, C., The Gods of Egypt, Cornell University Press, 2001, 85-86.

${ }^{3}$ Hornung, E., Conceptions of God in Egypt, Cornell University Press, 1996, 162-165.

${ }^{4} \mathrm{O}$. Kaelin, 'Ein vorderasiatisches Ideen-Cluster zur frühen Inszenierung des ägyptischen Herrschers', in: K. S. Schmidt, (ed.), Gedenkschrift für Mark A. Brandes (1929-2011), AOAT, 423; Münster: Ugarit-Verlag, 2015, 127-148.

${ }^{5}$ Wilkinson, R.H., Symbol and Magic in Egyptian Art (Thames\&Hudson,1999),183-229; Quirke,S., Exploring Religion in Ancient Egypt, Blackwell, 2014, 94-97.

${ }^{6}$ Goebs, K., 'Kingship' Toby Wilkinson, ed., The Egyptian World, London \&New York: Routledge, 2007, 275-295; Wilkinson, R.H.,The Complete Gods and Goddesses of Ancient Egypt, Thames \& Hudson, 2003, 54-63; Bonheme, M.A., 'Kingship', in: OEAE,II, 238ff; Franke, D., 'Kingship', in: OEAE,II, 245ff;
} 
them ${ }^{1}$ refers to the success of his previous roles, which depended on the support of the gods. ${ }^{2}$ Both mortuary and divine temple images and texts recorded the king performing political acts and ritual duties to the gods. ${ }^{3}$ These official religious practices and divine behaviour were believed to govern all nature and maintain Ma'at for the benefit of all Egypt. 4

c- irt-sntr ${ }^{5}-k b h^{6}$

Burning incense and libation was considered among the daily rites inside temples. They helped in the purification and nourishment of the god. ${ }^{7}$ Libation referred not only to purification, but also to the inundation. ${ }^{8}$

The scenes of burning incense and libation were either separated or joined, as in our stela. Combining them was popular in New Kingdom scenes, which showed the king performing

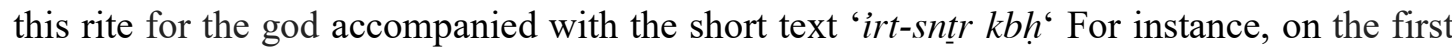
pylon of Luxor Temple, Ramesses III was depicted doing libation and fumigation to the god Sokar-Osiris. ${ }^{9}$ Another scene on the first pylon of Medinet Habu shows Ramesses III performing the same rite to the god Amon-Ra. ${ }^{10}$

d- The title ' $n b-h h^{\top} w$ ' 11 'Lord of Appearance' is an important royal title, especially from the New Kingdom onwards ${ }^{12}$. This title may be a mission statement for the

Hornung,E., Conceptions of God in Ancient Egypt, 191-196;V.Beckerath, B., 'König',in:L̈̈ III,461ff; Brunner-Traut,E., 'König-Gott-Verhältnis', in: LÄ III, 462-464.

${ }^{1}$ Bárta,.,M 'Egyptian Kingship during the Old Kingdom', In: Jane A. Hill, Philip Jones\& Antonio J. Morales, (eds.), Experiencing Power, Generating Authority: Cosmos, Politics, and the Ideology of Kingship in Ancient Egypt and Mesopotamia, Philadelphia: University of Pennsylvania Museum of Archaeology and Anthropology, 2013, 257-283; Stockfisch, D., Untersuchungen zum Totenkult des ägyptischen Königs im Alten Reich: die Dekoration der königlichen Totenkultanlagen (Antiquitates: Archäologische Forschungsergebnisse 25; Hamburg: Kovač, 2003.

${ }^{2}$ Weeks, K.R., 'Valley of The Kings', in: OEAE III, 471-474; Helck,W.H., Königsgräbertal', in: LÄ III, 468473.

${ }^{3}$ Schröder, S., Millionenjahrhaus: zur Konzeption des Raumes der Ewigkeit im konstellativen Königtum in Sprache, Architektur und Theologie, Wiesbaden: Harrassowitz, 2010; Heinz, S.C., Die Feldzugsdarstellungen des Neuen Reiches: eine Bildanalyse (Österreichische Akademie der Wissenschaften, Denkschriften der Gesamtakademie 18; Untersuchungen der Zweigstelle Kairo des Österreichischen Archäologischen Institutes 17; Vienna: Österreichische Akademie der Wissenschaften, 2001.

${ }^{4}$ Baines,J., 'Society, Morality, and Religious Practice', in: B. Shafer,Religion in Ancient Egypt: Gods, Myths, and Personal Practice, Cornell University Press, 1991, 126-127, for more see :Assmann, J., The Search for God in Ancient Egypt, Cornell University, Press, 2001.

${ }^{5} \mathrm{~Wb}$ IV, 180,18-22

${ }^{6} \mathrm{~Wb} \mathrm{~V}, 27,15-16$

${ }^{7}$ Poo, MU-Chou., Liquids in the Temple Ritual, UCLA, 2010, 4; Wise, E., An 'Odor of Sanctity': The Iconography, Magic and Ritual of Egyptian Incense, Studia Antiqua 7.1, Cambridge University Press, 2009, 69 ff; Borghouts, J.F., 'Libation', in: L̈̈ III, 1014-1015; Blackman, A., 'The significance of Incense and Libations in Funerary and Temple Ritual', in: Z̈̈S 50, 1912, 75ff

${ }^{8}$ Poo, MU-Chou., Liquids in the Temple Ritual, 5.

${ }^{9} \mathrm{MH}$ IV,P1.244,k

${ }^{10} \mathrm{MH}$ IV,Pl.245,A.

${ }^{11} \mathrm{~Wb}$ II, 228,10.

${ }^{12}$ For example, see: Collins, B., A history of the animal world in the ancient neareast, köln, 2002, 338; Traunecker, C., 'Un exemple de rite de substiution: une stéle de Nectanébo I' in: CAHKARN 7, Paris, 1982,341 .

- 45 - DOI: 10.36816/shedet.006.3 
king related to his appearance to the common people during feasts and ceremonies ${ }^{1}$ inside some accessible places in the forecourts inside the divine temples. ${ }^{2}$ These courts themselves had epithets relating to their function of place where the king's appearance happened. For instance, the first court was known as 'st- $h^{c}$ ', 'the place of appearance , 3 , and the second court was known as: "wsht hryt'the court of appearance 'and 'st h'yt 'the place of appearance' .

Furthermore, in both royal and temple palaces, one of their essential architectural elements is called 'šs $d-h^{c} w^{c}$ 'the Windows of appearance', through which the king appeared to the common people and foreign delegations during feasts and certain ceremonies. ${ }^{6}$

e- Thot is depicted here, in one of his main roles in the Ancient Egyptian religion, as the moon god allowing time to be measured. ${ }^{7} \mathrm{He}$ was considered as the reckoner of times and seasons because the moon cycles organised many of the Egyptian society's rituals and events, both religious and civil. Consequently, Thot was seen as a god of wisdom, magic, as well as measurement and regulation of events and time. ${ }^{8}$

As a moon god, Thot was commonly depicted as a seated baboon ${ }^{9}$ with or without a lunar disk on top of a crescent moon resting on his head. ${ }^{10}$

f- The god Thot wore the necklace of the goddess Ma'at ${ }^{11}$, which referred to their strong relationship, which appeared clearly in the Ancient Egyptian religion,for instance,

\footnotetext{
${ }^{1}$ Arnold, D., 'Wandrelief und Raumfunktion in ägyptischen tempeln des Neuenreiches' MÄS 2, 1962, 95; Kees, H., 'Die weise Kapelle Sesostris'I. in Karnak und das Sed Fest' , in: MDAIK 16 , 1958, 203.

${ }^{2}$ Roth, A.,'Social Change in the Fourth Dynasty, the Spatial Organization of Pyramids, Tombs, and Cemeteries', in: JARCE 30, 1993, 47ff.

${ }^{3}$ Abd El-Razik, M., 'The Dedicatory and Building Texts of Ramesses II in Luxor Temple, I, (The Texts)', in: JEA 60(1974)§ 7A; Id., 'The Dedicatory and Building Texts of Ramesses II in Luxor Temple, II, (Interpretation)' in: JEA 61, 1975,130-131.

${ }^{4}$ Christophe, L., 'La face sud des architraves surmontant les colonnes de la grande salle hypostyle de Karnak' , in: BIFAO 60, 1960, $77 \mathrm{~A} 1$.

${ }^{5} \mathrm{~Wb}, \mathrm{IV}, 302-303,3-4 ;$ LDLE II,83.

${ }^{6}$ Arnold, D., The Pharaohs, Italy, 2002, 271;Shaw, I. \& Nicholson, P., The British Museum Dictionary of Ancient Egypt, The American University in Cairo Press, 1995, 216; Uphill, E.P., 'The Concept of the Egyptian Palace as a Ruling Machine', in Man, Settlement and Urbanism, ed. by P. Ucko, London, 1972, 721f; Badawy, A., A History of Egyptian Architecture, the Empire (The New Kingdom), Los Angeles, 1968, 33; Davies, N. de G., 'The Place of Audience in the Palace', in: Z̈̈S 60, 1925, 50-56; Stadelmann, R., "Tempelpalast und Erscheinungsfenster in den Thebanischen totentempeln", 224; Carter, H., 'Report on the Work done at Ramesseum during the Year 1900-1901', in: ASAE 2, 1901, 3ff.

${ }^{8}$ Nolan, J. S., Lunar intercalations and 'cattle counts'during the Old Kingdom: the Hebsed in context , Prague, 2008, 44

${ }^{8}$ Assmann, J., The Search for God in Ancient Egypt, 80-81.

${ }^{9}$ According to the Ancient Egyptian religion, the sacred animal of a god was worshiped as the manifestation of the god's power on earth and bore its spirit 'b3'. For more information, see: A. Sadek.,'Popular Religion in Egypt during the New Kingdom', Ḧ̈B 27, 1987, 162; Hornung, E., Der Ägyptische Mythos von der Himmelskuh, Freiburg-Gootingen, 1982, 80f; Morenz, S.. Egyptian Religion, London, 1973, 165-166; RARG,113; E. Otto, Die Biographischen Inschriften der Ägyptischen Spätzeit, Leiden, 1954, 36; Hopfner, T., Fontes Historiae Religionis Äegyptiacae, Bonn, 1923, 352 Hornung, E., Conceptions of God in Ancient Egypt, 138.

${ }^{10}$ Budge, W., The gods the Egyptians or Studies in Egyptian Mythology, Vol. I, London, 1904, 401.

${ }^{11}$ Ma'at was the Ancient Egyptian goddess of truth, balance, order, harmony, law, morality, and justice. Her ideological opposite was Isfet, injustice, chaos, and violence. The earliest records of Ma'at date to the Old Kingdom, in the Pyramid Texts of Unas. She represented values of justice that had to be carried out in the spirit of truth and fairness, judges wore images of Ma'at. She was depicted either as a woman with wings on
} 
*Thot was considered the husband of Ma' at. ${ }^{1}$

*During the deceased's final judgment in the underworld in the Hall of Truth. ${ }^{2}$ Thot was the god of equilibrium who reported on the scales weighing the deceased's heart against the feather of Ma'at. ${ }^{3}$

*Thot was regularly depicted with a symbol of Ma'at, either as a baboon wearing the necklace of the goddess Ma'at, as an ibis accompanied with Ma'at or the feather of Ma'at resting on his beak. ${ }^{4}$

*Thot had many titles related to Ma'at, such as ' $n b-m 3^{\top} t$ ', 'Lord of Ma'at' ' $s \check{s}-m 3^{\top} t$ ' 'Scribe of Ma'at', and 'mry-m3't' 'Beloved of Ma'at'.

g- The name of Thot is written in front of his figure /

This confirms the identity of the moon god, as many gods played the moon god's role, such as Khonsu and Osiris. ${ }^{6}$ Recording the name of Thot avoids any confusion, especially between Thot and the moon's god Khonsu ${ }^{7}$, who bore strong similarities with Thot ${ }^{8}$ and whose cult spread in the New Kingdom ${ }^{9}$.Khonsu was also depicted as a baboon with a headdress of the lunar disk on top of a crescent moon. ${ }^{10}$ Furthermore Ounû was not from the central cult places of Thot. ${ }^{11}$

each arm or as a woman with an ostrich feather on her head.See: Allen, J.P., Middle Egyptian: An Introduction to the Language and Culture of Hieroglyphs, Cambridge University Press, 2000, 116; Morenz, S., Egyptian Religion, London, 1973, 117-125 273; Budge,W., The gods the Egyptians or Studies in Egyptian Mythology, Vol. I, 416 ; For more information about Ma'at, see: Helck,W.,'Maât',in: LÄ III, 1110-1119; Karenga, M. N., Maat, The Moral ideal in ancient Egypt: A study in classical ethics I, California, 1994; Assmann, J., Ma'at: Gerichtigkeit und Unsterblichkeit im Alten Ägypten, München, 1990;Id., Maât.L'Egypte Pharaonique et L'idèe de Justice Sociale, Paris, 1988; Beinlich,H., 'Maat', in: LÄ III, 1110-1119.

${ }^{1}$ Allen, J.P., Middle Egyptian: An Introduction to the Language and Culture of Hieroglyphs, 44-.25.

${ }^{2}$ Martin, A.S.,'Thoth', In: UCLA Encyclopedia of Egyptology, ed. by W. Wendrich ,UCLA, Los Angeles, 2012, 26

; Andrews,C., Amulets of Ancient Egypt, Austin: University of Texas, 1994, $27,49$.

${ }^{3}$ Budge,W., The gods the Egyptians or Studies in Egyptian Mythology,Vol. I, 403

${ }^{4}$ Nasr El-Dine,H.,'Trois Figurines D'Ibis Avec Maat', in: ASAE 86, 2012/2013, 321-328; Menu,B.,'Le Tombeau de Petosrirs II,Maat, Thot et le Droit', in: BIFAO 95, 1995, 281-295.

${ }^{5}$ The Essential Guide to Egyptian Mythology: The Oxford Guide, Berkeley, 2003, 190.

${ }^{6}$ Birch, S., Notes upon an Egyptian Iscription in the Bibliothèque Nationale of Paris, London, 1850, 218; Fowden, G., Hermès l'Égyptien , Paris, 2000, 57; Volokhine, Y., 'Le Dieu Thot au Qasr el-Agouz', in: BIFAO 102, 2002, 141; Id., 'Le Dieu Thot et la Parole', in: RHR 221, 2004; Korostovtzeff , M. , 'Stèle de Ramsès IV', in: BIFAO 45, 1945 , p.161; Griffiths , J.,'Osiris and the Moon in Iconogrphy',in: JEA 62, 1976, 153 - 159; Ritner, R. K., 'Anubis and the Lunar Disc', in: JEA 71, 1985, 152; Armour, A., Gods and Myths of Ancient Egypt, Cairo, 1986, 148.

${ }^{7}$ Candeias, J., Estudos d'Egiptologia: Temáticas e Problemáticas, Belo, 2007, 174; Teeter, E., Scarabs, Scaraboids, Seals, and Seal impressions from Medinet Habu, Chicago, 2003, 57;Black, J.R., The Instruction of Amenemope, Wisconsin-Madison, 2002, 526.

${ }^{8}$ Gómez, A., The Personnel of Khonsu during the Third Intermediate Period at Thebes: A Prosopographical Study of the $21^{\text {st }}$ Dynasty, Madrid, 2015, 17.

${ }^{9}$ Gómez, A., The Personnel of Khonsu during the Third Intermediate Period at Thebes, 17.

${ }^{10}$ Bénédite,G., 'Scribe et Babouins', in: $A I B L$ 19, Paris, 1911, 5; Montet, P., 'Chonsou et son Serviteur', in: Kêmi 12, 1952, 59 - 76, pls. III,IV; Brunner, H., 'Chons',in: LÄ I, 960-963;Wegner,J.H., 'Khonsu', in: OAEA II, $233 \mathrm{ff}$.

${ }^{11}$ Thot was worshipped in many places, but its two central cult places were Hermopolis Magna and Saqqara. For more information, see: Maurer, K.,'Der Tierfriedhof von Tuna el-Gebel in frühptolemäischer Zeit', in: J. Mylonopoulos\& H. Roeder (eds.), Archäeologie und Ritual: Auf der Suche nach der rituellen Handlung inden antiken Kulturen Ägyptens und Griechenlandes, Wein, 2006, 116; Smith, A., A visit to Ancient Egypt, Life

- 47 - DOI: $10.36816 /$ shedet.006.3 


\section{Conclusions:}

This article publishes two blocks from Heliopolis, dated to The New Kingdom.

\section{The first block:}

The first block is dated to the reign of the king Ramesses II. It has a finely scene depicts a figure of the Nile-god Hapy in a kneeling posture, lifting, on his hands, a flat offering-table presenting to the cartouche of Ramesses II, who had the titles : $n b$ t3wy (wsr-m3`t $R^{\top}-\operatorname{stp} n R^{\top}$ )

"The lord of the two lands (Weser-Ma'at Re, setepen-Re)."

\section{The second block:}

The second block is dated to the reign of the king Ramesses V. It has a scene shows part of the figure of the king Ramesses $\mathrm{V}$ kneeling, performing fumigation and libation before the sacred-figure of the god Thoth ${ }^{1}$, in the form of a seated baboon. The king had the titles:

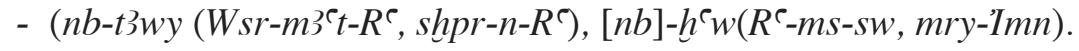

"The lord of the two lands (Weser-Ma'at-Re,sekheper-en-Re), The lord of appearance , Ramesses the beloved of Amon".

- $\quad\left(n b-h^{\top} w\left(R^{\top}-m s-s w, m r y-I m n\right)\right.$

"The lord of appearance, Ramesses the beloved of Amon"

at Memphis and Saqqara, Warminster, (1974), 42 f; Gabra, S., Fouilles de Hermopolis Ouest, Le Caire, 1954, 11ff; Smith, H.S., 'Preliminary Report on Excavations in the Sacred Animals Necropolis',in: JEA 62 1976, 14; Van den- Driesch,A\& Kessler,D\& Peters,J., 'Mummified baboons and Other Primates from the Saitic-Ptolemaic Animal Necropolis of Tuna el-Gebel, Middle Egypt', Documenta Archaeobiologiae 2, 2004, 236.

${ }^{1}$ The god Thot was one of the most important gods in the Ancient Egyptian religion. He had two sacred animals; the ibis and the baboon. For more information about his aspects and his roles in the Ancient Egyptian religion, see: El-Sayed ,A. M., La Mythologie Egyptienne, Paris , 1998, 106; D. Kessler, 'Der Gott Thot-stier', in: D. Kessler \& R. Schluz (Hrsg.), Gedenkschrift für winfried Barta, htp di n hzj, Frankfort, 1995, 229-245;Brunner-Traut,E., 'Affe', in: L̈̈ I, 83ff; Zivie,A.,'Ibis',in: L̈̈ III, 115ff; Boylon, P., Thoth,The Hermes of Egypt, Oxford, 1922, 5ff. 


\section{REFERENCES}

- Abd el-Gelil, M \& Suleiman, R\& Faris, G\& Raue, D. ,'The joint Egyptian-German Excavations in Heliopolis in Autumn 2005', in: MDAIK 64, (2008).

- Id., \& Shaker, M\& Raue, D., 'Recent Excavations at Heliopolis', in: Or 65, (1996).

- Abd El-Razik, M., 'The Dedicatory and Building Texts of Ramesses II in Luxor Temple, II, (Interpretation)', in: JEA 61, (1975).

- Id., 'The Dedicatory and Building Texts of Ramesses II in Luxor Temple, I, (The Texts), in: JEA 60, (1974).

- Allen, J.P., 'Heliopolis', in: OEAE II, Oxford, (2001).

- Id., Middle Egyptian: An Introduction to the Language and Culture of Hieroglyphs (Cambridge University Press, 2000).

- Andrews, C., Amulets of Ancient Egypt,(Austin: University of Texas,1994).

- Armour, A., Gods and Myths of Ancient Egypt (Cairo, 1986).

- Arnold. D., The Pharaohs (Italy, 2002).

- Id., 'Wandrelief und Raumfunktion in ägyptischen tempeln des Neuenreiches', MÄS 2, (1962).

- Ashmawy, A \& Raue, D., 'The Temple of Heliopolis: excavations 2012 -2014', in: Egyptian Archaeology EES-Bulletin 46, (2015).

- Ashmawy, A \& Raue, D \& Beiersdorf, M., 'The Thirtieth Dynasty in the Temple of Heliopolis', in: Egyptian Archaeology EES-Bulletin 47, (2015).

- Assmann, J., Ma'at : Gerichtigkeit und Unsterblichkeit im Alten Ägypten, München , (1990)

- Id., The Search for God in Ancient Egypt, Cornell University Press, (2001).

- Id., ' Nilhymnus', in: L̈̈ IV, (1982).

- Id ., Maât.L'Egypte Pharaonique et L'idèe de Justice Sociale, Paris, (1988).

- Id., The Search for Gods in Ancient Egypt, Cornell University Press, (2001).

- Id., 'Schöfung', in: LÄ VI, (1986).

- Badawy, A., A History of Egyptian Architecture, the Empire (The New Kingdom), Los Angeles, (1968).

- Baines , J., 'The Inundation Stela of Sebekhotpe VIII', in: AcOr 36, (1974).

- Id., 'Society, Morality, and Religious Practice', In: B. Shafer., Religion in Ancient Egypt: Gods, Myths, and Personal Practice, Cornell University Press, (1991).

- Id., 'The Sebekhotpe VIII Inundation Stela, An Aditional Fragment', in: AcOr37, (1976).

- Id., Fecundity Figures: Egyptian Personification and the Iconology of a Genre, Warminster, (1985).

- Bakry, H.S., The Discovery of Temple of Mernptah at On, in: Aegyptus 53, (1973).

- Baines, J.\& Melek, J., Atlas of Ancient Egypt, NewYork, (1964).

- Balboush, M., 'Preliminary Export on the New Discovery of the Temple of Ramesses II at Heliopolis', in: ASAE 63 (1979).

- Barguet,P., Le Temple d' Amon-Ré à Karnak, in: RAPH21, (1962).

- Id.,'La Stéle de La Famine à Sehel', in: BDE 23, (1953).

- Bárta,.,M 'Egyptian Kingship during the Old Kingdom', Jane A. Hill\& Philip Jones \& Antonio J. Morales, eds., Experiencing Power, Generating Authority: Cosmos, Politics, and the Ideology of Kingship in Ancient Egypt and Mesopotamia (Philadelphia: University of Pennsylvania Museum of Archaeology and Anthropology, 2013).

- Beinlich, H., 'Altagyptischen Raucheram', in: MDAIK 34, (1987).

- Id., 'Maat, in: $L \ddot{A}$ III (1980)

- Bénédite, G., 'Scribe et Babouins', in: AIBL 19, Paris, (1911).

- Benezet, N.T., 'Geograpie Sacree dans l'Egypt Ancienne :Methodologie er Perspectives a Partir de l'Etude du Territoire des Deux Sceptres -wAs', Bellaterra, (2012). 
- Bierbrier, M. L. (ed), Papyrus: Structure and Usage. British Museum Occasional Paper 60, London, (1986).

- Birch, S., Notes upon an Egyptian Iscription in the Bibliothèque Nationale of Paris, London, (1850).

- Black, J.R., The Instruction of Amenemope, Wisconsin-Madison (2002).

- Blackman, A., 'The significance of Incense and Libations in Funerary and Temple Ritual', in: ZÄS 50, (1912).

- Bonheme, M.A., 'Kingship', in: OEAE, II, Oxford, (2001).

- Bonneau, D., La Cure du Nil ,Divinité Égyptienne à Travers Mille Ans d'histoire,Études et Commentaires 52, Paris, (1964).

- Borghouts, J.F., 'Libation', in: LÄ III, (1980)

- Boylon, P., Thoth: The Hermes of Egypt, Oxford, (1922).

- Brunner, H., 'Chons', in: $L \ddot{A}$ I, (1975).

- Brunner-Traut, E., 'Affe, in: $L \ddot{A}$ I (1975)

- Id., 'König-Gott-Verhältnis', in: L $2 \ddot{A}$ III,(1980)

- Budge, W., The gods the Egyptians or Studies in Egyptian Mythology, Vol. I , London, (1904).

- Candeias, J., Estudos d'Egiptologia: Temáticas e Problemáticas, Belo , (2007).

- Carter, H., "Report on the Work done at Ramesseum during the Year 1900-1901' , in: ASAE 2, (1901).

- Christophe, L., 'La face sud des architraves surmontant les colonnes de la grande salle hypostyle de Karnak', in: BIFAO 60, (1960).

- Collins, B., A History of the Animal World in the Ancient Near-east, köln, (2002).

- Davies, N. de G., 'The Place of Audience in the Palace', in: ZÄS 60, (1925).

- De Dapper, M \& Herbich, T., 'Geomorphological and geophysical survey', in: Egyptian Archaeology EES-Bulletin 46, (2015).

- El-Sayed, A. M., La Mythologie Egyptienne, Paris, (1998).

- Essam, B., 'Le Voyage à Héliopolis descriptions des Vestige Pharaonique et des Traditions Associèes depuis Herodote Juaqu à L'Expditions d'Egypte', in: RAPH 36, Le Caire ,(2014).

- Evers, H.G,Staat aus dem Stein vol. I, München, (1929).

- Firth, C.M., The Archaeological Survey of Nubia Report for 1910-1911, Cairo, (1927).

- Fischer, H., 'Varia Aegyptiaca 4, The Evolution of Armlike Censer', in: JARCE 2, (1963).

- Fowden, G., Hermès l'Égyptien, Paris, (2000).

- Franke, D., 'Kingship', in: OEAE,II , Oxford, (2001).

- Gabra, S.,Fouilles de Hermopolis Ouest, Le Caire, (1954).

- Goebs,K., 'Kingship' Toby Wilkinson, ed., The Egyptian World, London \&New York: Routledge, (2007).

- Gómez, A., The Personnel of Khonsu during the Third Intermediate Period at Thebes: A Prosopographical Study of the $21^{\text {st }}$ Dynasty, Madrid, (2015).

- Griffiths , J., 'Osiris and the Moon in Iconogrphy', in: JEA 62, (1976).

- Habachi, L., 'Hight Inundation in the Temple of Amenre at Karnak in the $13^{\text {th }}$ dynasty', in: SAK 1, (1974).

- Hannig, R., Ägyptisches Wörterbuch II, Mittleres Reich und Zweite Zwischenzeit, Teil I, Mainz Am Rhein, (2006).

- Hart, G., The Routledge Dictionary of Egyptian Gods and Goddesses, Routledge, (2005).

- Hassan, R., Le Papyrus, Cairo, (1980).

- Heinz, S.C., Die Feldzugsdarstellungen des Neuen Reiches: eine Bildanalyse (Österreichische Akademie der Wissenschaften, Denkschriften der Gesamtakademie 18; Untersuchungen der Zweigstelle Kairo des Österreichischen Archäologischen Institutes 17; Vienna: Österreichische Akademie der Wissenschaften, (2001).

- Helck,W., Der Text des 'Nilhymnus'(Kleine ägyptische Texte, 4; Wiesbaden: Otto Harrassowitz, (1972). 
- Id., 'Maât', in: LÄ III, (1980).

- Id., ‘ Königsgräbertal', in: $L \ddot{A}$ III, (1980).

- Hopfner, T., Fontes Historiae Religionis Äegyptiacae, Bonn, (1923).

- Hornung, E., Conceptions of God in Egypt, Cornell University Press, (1996).

- Id., Der Ägyptische Mythos von der Himmelskuh (Freiburg-Gootingen, 1982).

- Hovestreydt,W., 'Secret Doors and Hidden Treasure: Some Aspects of Egyptian Temple Treasuries from the New Kingdom', in: Egyptological Memoirs 1, Essays on Ancient Egypt in Honour of Herman te Velde,ed.by J.Van Dijk, Groningen, (1997).

- Jéquier, G, Le Monument Funéraire de Pépi,II, II, (Le temple), Le Caire, (1938).

- Johnston,S.I., Religions of the Ancient World, Cambridge University Press, (2004).

- Kaelin, O., 'Ein vorderasiatisches Ideen-Cluster zur frühen Inszenierung des ägyptischen Herrschers, ' in :K. S. Schmidt, ed., Gedenkschrift für Mark A. Brandes (19292011) (AOAT 423; Münster: Ugarit-Verlag, (2015).

- Karenga, M. N., Maat, The Moral ideal in ancient Egypt: A study in classical ethics I, California, (1994).

- Kees, H., 'Die weise Kapelle Sesostris'I. in Karnak und das Sed Fest', in: MDAIK 16, (1958).

- Kessler, D., 'Der Gott Thot-stier', in: D. Kessler \& R Schluz (Hrsg.), Gedenkschrift für winfried Barta, htp di $n$ hzj, Frankfort, (1995).

- Korostovtzeff, M. , 'Stèle de Ramsès IV', in: BIFAO 45, (1945).

- Loo, A. V\& Bruwier, M.C .,Héliopolis, Bruxelles, (2010).

- Martin, A. S., 'Thoth', in: UCLA Encyclopedia of Egyptology, edited by W. Wendrich, UCLA, Los Angeles, (2012).

- Marwan, N.Z.,Egyptian Agriculture Life in the New Kingdom, Cairo, (1989).

- Maurer, K.,'Der Tierfriedhof von Tuna el-Gebel in frühptolemäischer Zeit', in: J. Mylonopoulos\& H. Roeder (eds.), Archäeologie und Ritual: Auf der Suche nach der rituellen Handlung inden antiken Kulturen Ägyptens und Griechenlandes, Wein, (2006)

- Menu, B., 'Le Tombeau de Petosrirs II,Maat,Thot et le Droit', in: BIFAO 95,(1995).

- Mohammed, A.G., 'The Joint Egyptian German Excavations in Heliopolis in autumn 2005', in: MDAIK 64, (2008).

- $\quad$ Montet, P., 'Chonsou et son Serviteur', in: Kêmi 12, (1952).

- Morenz, S., Egyptian Religion, London, (1973).

- Mouris, M.I \& Balbousch, M.,'Funde aus dem Temple Ramses II‘ im Tell el-Hisn bei Heliopolis', in: MDAIK 31, (1975).

- Moursi, M., 'Die Hohenpriester des Sonnengottes von der Frühzeit Ägyptens bis zum Ende des Neuen Reiches', MÄS 26, (1972).

- Naphtali, L., Papyrus in Classical Antiquity, Oxford, (1974)

- Nasr El-Dine, H., 'Trois Figurines D'Ibis Avec Maat', in: ASAE 86, (2012/2013).

- Nolan, J. S., Lunar intercalations and 'cattle counts 'during the Old Kingdom: the Hebsed in context, Prague, (2008).

- Otto , E., Die Biographischen Inschriften der Ägyptischen Spätzeit, Leiden, (1954).

- Patrik, K., All Colour Book of Egyptian Mythology, London, (1989).

- Petrie, F., Abydos II, EEF 24, (1903).

- Poo, MU-Chou., Liquids in the Temple Ritual, UCLA, (2010).

- Quirke, S., Exploring Religion in Ancient Egypt, Blackwell, (2014).

- Radwan, A., 'Zur Stellung des Königs in der Zweiten Zwischen Zeit', in: TÄB 30, (1990).

- Raue, D., Ein Wesir Ramses' II. in: Stationen, Beiträge zur Kulturgeschichte Ägyptens Rainer Stadelmann gewidmet. (ed) by Heike Gusch, H\& Polz. D, Mainz, (1998).

- Richard, P\& Quirke, S., Papyrus, London, (1995).

- Ritner, R. K., 'Anubis and the Lunar Disc', in: JEA 71, (1985).

- Roader, G, Kulte und Orakel in Alten Ägypten, Zurich, (1960). 
- Rodot, V\& Gabolde, L., 'Karnak, Precinct of Montu',Encyclopedia of the Archaeology of Ancient Egypt,(ed.) by K.A. Bard, NewYork , (1999).

- $\quad$ Rosemarie, D., 'Papyrus, -herstellung', in: L̈̈ IV, (1982)

- Roth, A., 'Social Change in the Fourth Dynasty, the Spatial Organization of Pyramids, Tombs, and Cemeteries', in: JARCE 30, (1993).

- Sadek, A., 'Popular Religion in Egypt during the New Kingdom', in: HÄB 27, (1987).

- Saleh, A., Excavations at Heliopolis, Ancient Egyptian OUNU, vol I, Cairo, (1981).

- Id., Excavations at Heliopolis, Ancient Egyptian OUNU, vol II, Cairo, (1983).

- Schröder, S., Millionenjahrhaus: zur Konzeption des Raumes der Ewigkeit im konstellativen Königtum in Sprache, Architektur und Theologie, Wiesbaden: Harrassowitz, (2010).

- Shaw, J., 'Balustrades, Stairs and Altars in the Cult of the Aten at el-Amarna', in: JEA 80, (1994).

- Selon, W.M.V, Egyptians Legends and Stories, London, (1988).

- Shaw, I. \& Nicholson, P., The British Museum Dictionary of Ancient Egypt, The American University in Cairo Press, (1995).

- Smith, A., A visit to Ancient Egypt, Life at Memphis and Saqqara, Warminster, (1974).

- Smith, H.S., 'Preliminary Report on Excavations in the Sacred Animals Necropolis', in: JEA 62, (1976).

- Sourouzian, H., 'Statues et representations de statues royales sous Sethi I', in: MDAIK 49, (1993).

- Id., 'Standing royal colossi of the Middle Kingdom reused by Ramesses II', in: MDAIK 44, (1988).

- Spence, L., Myths \& Legends of Ancient Egypt, New York, (2008).

- Stadelmann, R. 'Tempelpalast und Erscheinungsfenster in den thebanischen Totentempeln', in: MDAIK 29, (1973).

- Stern,L., 'Die Nile Stele von Gabel Silsileh', in: Z̈̈S 1, (1873).

- Stockfisch, D., Untersuchungen zum Totenkult des ägyptischen Königs im Alten Reich: die Dekoration der königlichen Totenkultanlagen(Antiquitates: Archäologische Forschungsergebnisse 25; Hamburg: Kovač, (2003).

- Teeter, E., Scarabs, Scaraboids, Seals, and Seal impressions from Medinet Habu, Chicago, (2003).

- Traunecker, C., The Gods of Egypt, Cornell University Press, (2001).

- Id.,'Un exemple de rite de substiution: une stéle de Nectanébo I ', in: CAHKARN 7, Paris, (1982).

- Uphill, E.P., 'The Concept of the Egyptian Palace as a Ruling Machine', in Man, Settlement and Urbanism, (ed.) by P. Ucko, London, (1972).

- Van den- Driesch, A \& Kessler, D \& Peters, J., 'Mummified baboons and Other Primates from the Saitic-Ptolemaic Animal Necropolis of Tuna el-Gebel, Middle Egypt', Documenta Archaeobiologiae 2, (2004).

- Volokhine, Y., 'Le Dieu Thot et la Parole', in: RHR 221, (2004).

- Id., 'Le Dieu Thot au Qasr el-Agouz', in: BIFAO 102, (2002).

- Von-Beckerath, B.,'Handbuch der Agyptischen Konigsnamen', MÄS 20, (1984).

- Id., 'König', in: $L \ddot{A}$ II, (1977).

- Weeks,K.R.,' Valley of The Kings', in: OEAE III, Oxford, (2001)

- Wegner, J.H.,'Khonsu', in: OAEA, II, Oxford, (2001)

- Weidner, S., Lotos im Alten Ägypten, vorabeiten zu einer Kulturgeschichte von Nymphaea Lotos, Nymphaea Coerulea und Nelumbo Uncifera in der Dynastischenzeit, (1985).

- Wessetzky, V., 'Nun', in: LÄ IV, (1982).

- White, M., Ancient Egypt, London, (1992).

- Wilkinson, R.H., The Complete Gods and Goddesses of Ancient Egypt, Thames \& Hudson, (2003). 
- Id., Symbol and Magic in Egyptian Art, Thames \&Hudson, (1999).

- Id., The Complete Temples of Ancient Egypt, Thames \&Hudson, (2000).

- Wise, E., An Odor of Sanctity': The Iconography, Magic and Ritual of Egyptian Incense, Studia Antiqua 7.1, (Cambridge University Press).

- Wolf, W., Die Kunst Äegypten, Leipzig, (1959).

- Zivie, A., 'Ibis', in: LÄ III, (1980 ).

\section{ONLINE SOURCES}

- Ashmawy, A \& Raue, D\& Breninek, C\& Dietze, K\& Graichen, T\& Schulz,S., Report on the work of the Egyptian-German Mission at Matariya/Heliopolis in autumn 2015 and spring (2016).

- Ashmawy, A\& Raue, D \& Daniel, R., Von Elephantine bis zu den Küsten des Meeres: Die Kulttopog raphie Ägyptens nach den Gauprozessionen der Spätzeit und der frühptolemäischen Epoche ,Studien zur spätägyptischen Religion, 24,Gebundenes Buch ( August 2019).

- Eldamaty, M., 'Recent Excavations at Arab el-Hisn', A lecture in 'Daily Life in Ancient Egyptian Settlement, Conference to Celebrate the fiftieth Anniversary of Excavations on Elephantine Island (May 2019).

- Maria, S.A., Re-excavating Heliopolis, Unpublished Archaeological Data from the Archives of Ernsto Schiaparelli and Missione Archeologica Italiana (2014). 


\section{THE PLATES}

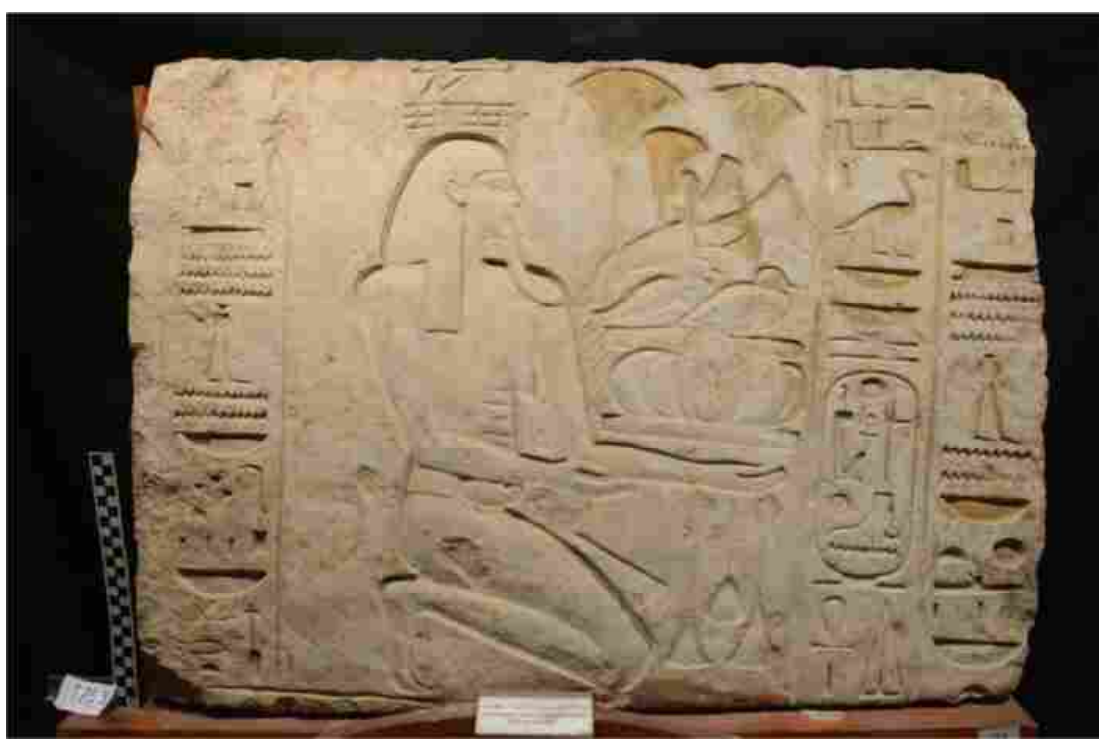

Pl. 1: Block of Ramesses II

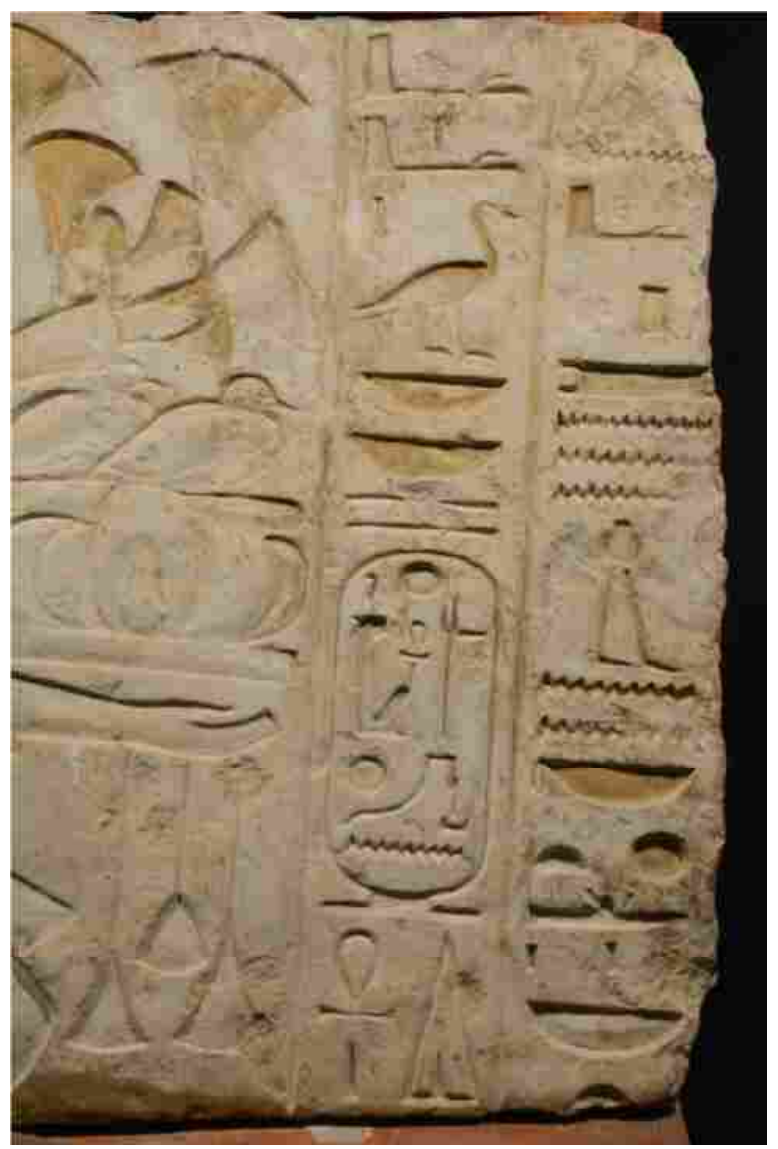

P1. 2: Texts in front of Hapy 


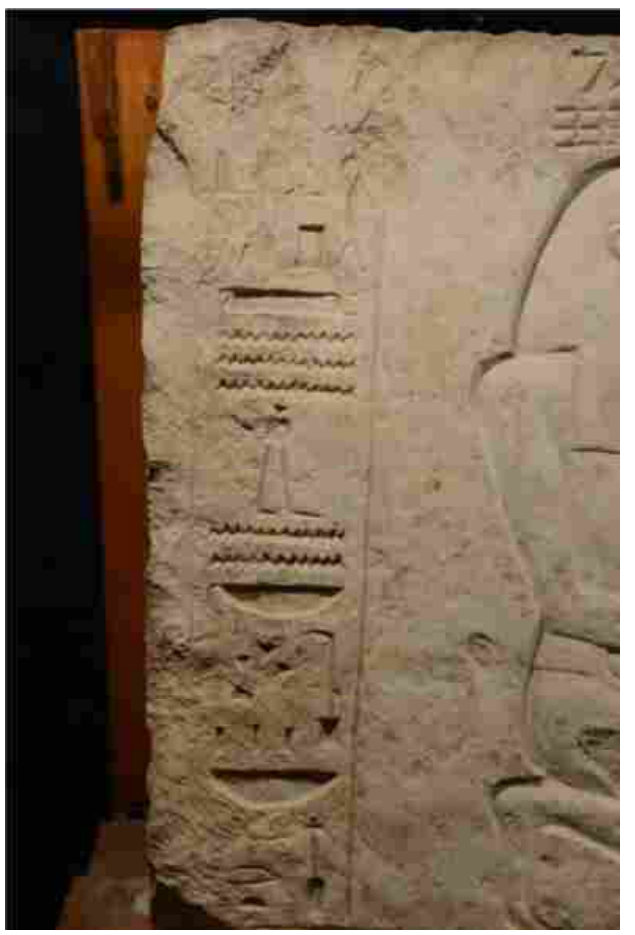

P1.3: The Text behind Hapy

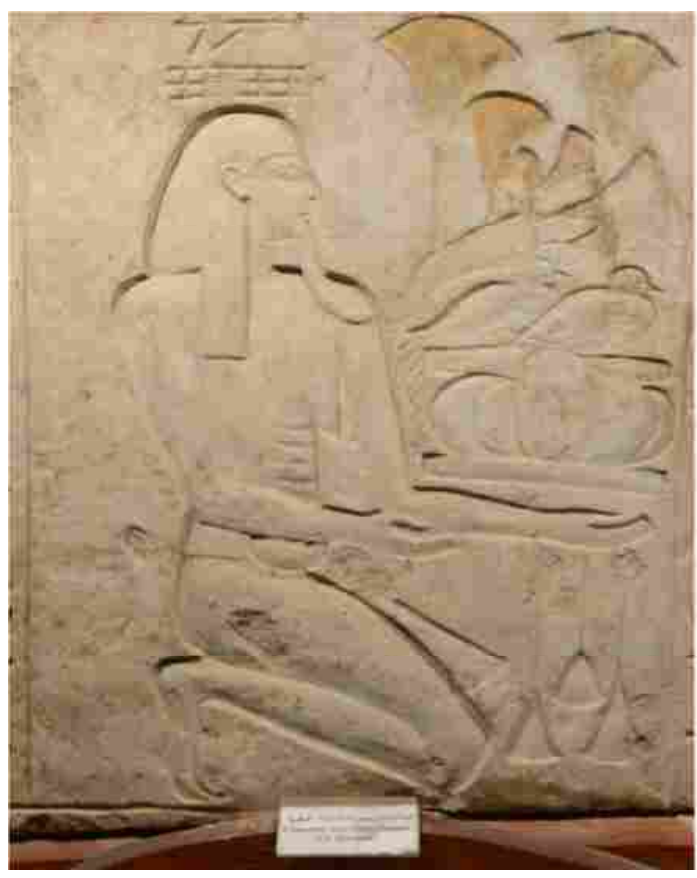

P1.4: Hapy Presenting Offerings. 


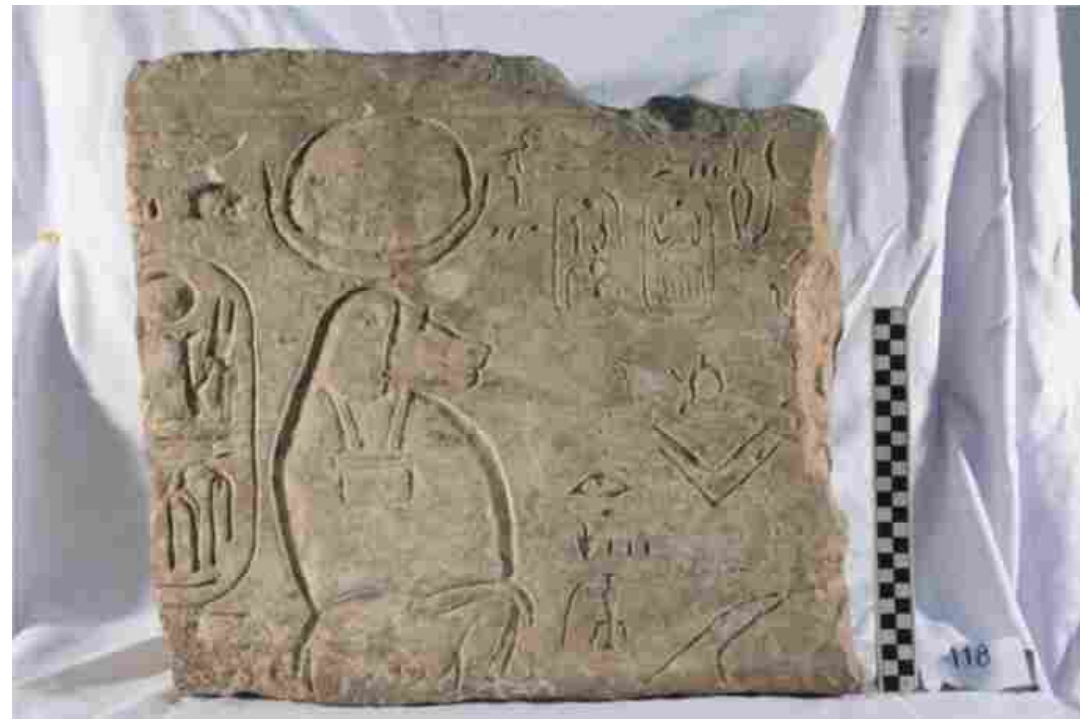

P1.5: Block of Ramesses V

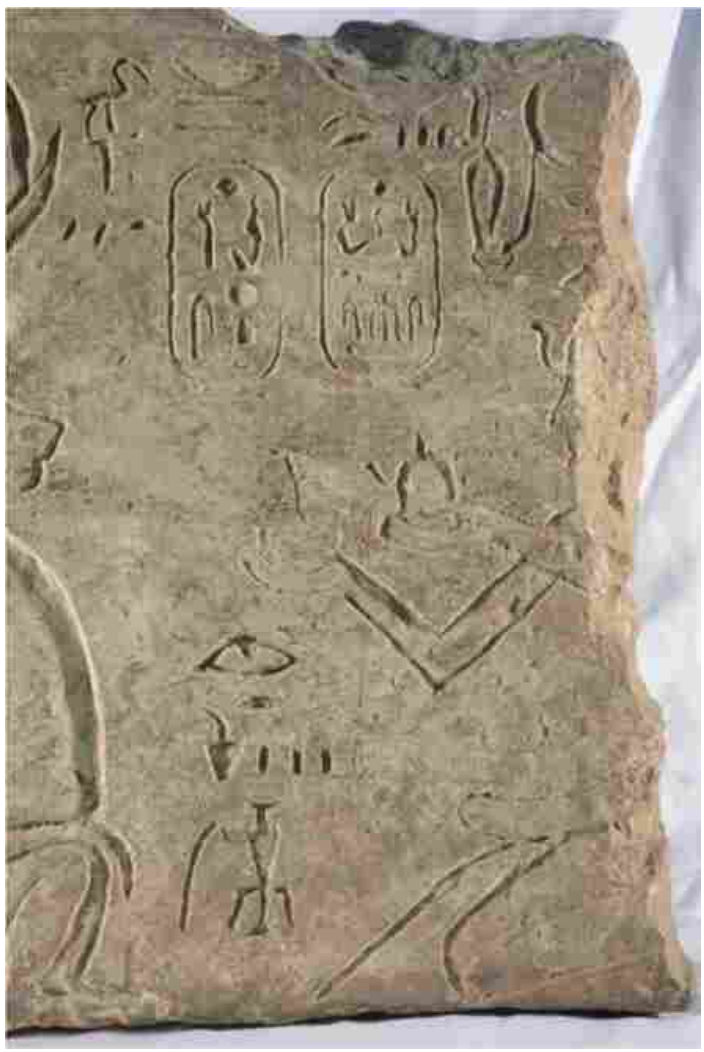

P1.6: Ramesses V Performing Fumigation and Libation and the texts in front him. 


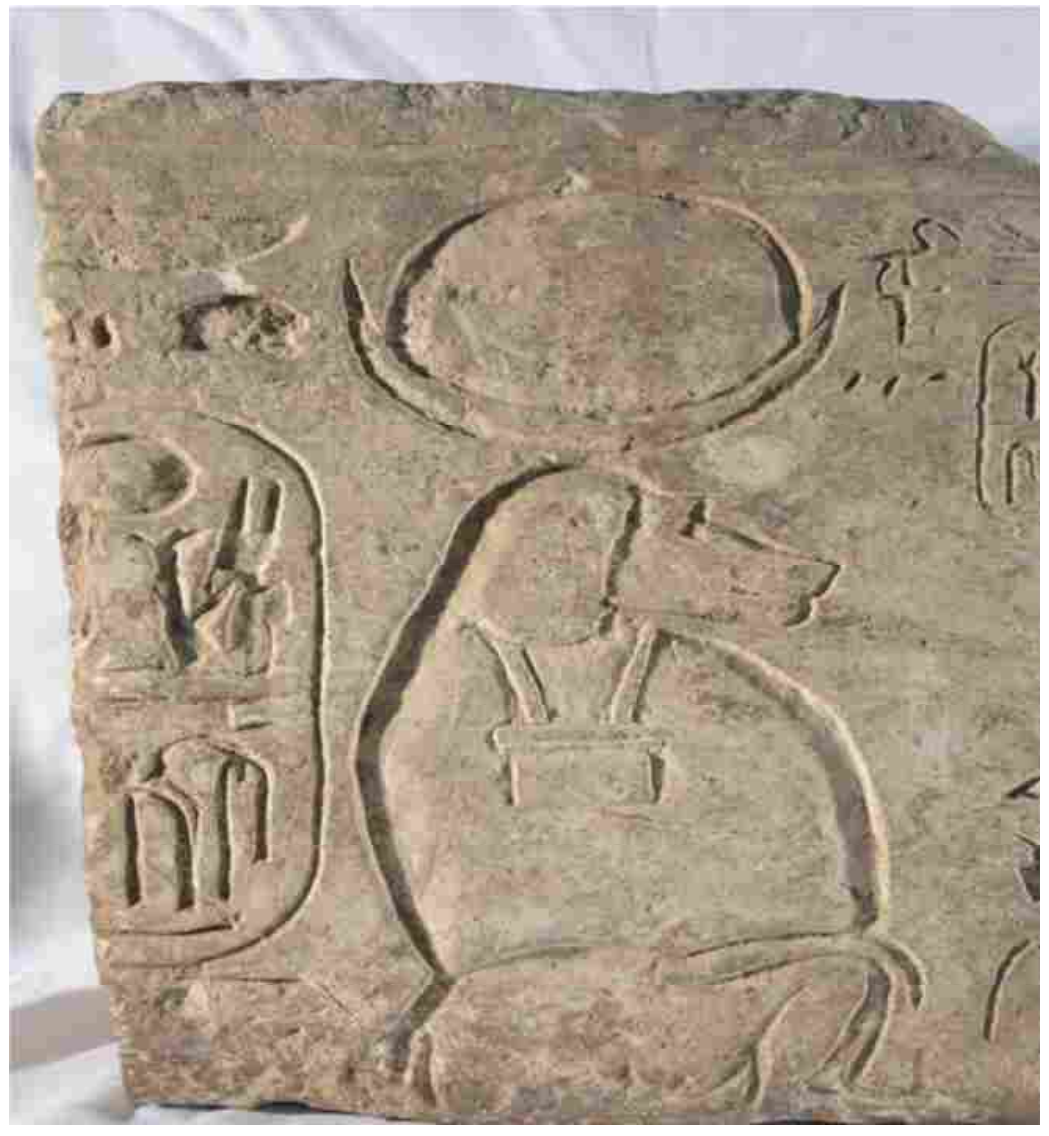

P1.7: Thot and the texts in front and behind him. 